\title{
Plasticity of foot muscle and cardiac thermal limits in the limpet Lottia limatula from locations with differing temperatures
}

\author{
Terrance Wang ${ }^{1, *}$, Richelle L. Tanner ${ }^{1,2}$, Eric J. Armstrong ${ }^{1,2}$, David R. Lindberg ${ }^{1,3}$, \\ Jonathon H. Stillman ${ }^{1,2}$ \\ ${ }^{1}$ Department of Integrative Biology, University of California, 3040 Valley Life Sciences Building \#3140, Berkeley, \\ CA 94720-3140, USA \\ ${ }^{2}$ Estuary \& Ocean Science Center and Department of Biology, Romberg Tiburon Campus, San Francisco State University, \\ 3150 Paradise Drive, Tiburon, CA 94920, USA \\ ${ }^{3}$ Museum of Paleontology, University of California, 1101 Valley Life Sciences Building, Berkeley, CA 94720-4780, USA
}

\begin{abstract}
Species distributions are shifting in response to increased habitat temperatures as a result of ongoing climate change. Understanding variation in physiological plasticity among species and populations is important for predicting these distribution shifts. Interspecific variation in intertidal ectotherms' short-term thermal plasticity has been well established. However, intraspecific variation among populations from differing thermal habitats remains a question pertinent to understanding the effects of climate change on species' ranges. In this study, we explored upper thermal tolerance limits and plasticity of those limits using a foot muscle metric and 2 cardiac metrics (Arrhenius breakpoint temperature, ABT, and flatline temperature, FLT) in adult file limpets Lottia limatula. Limpets were collected from thermally different coastal and inland-estuarine habitats and held for 2 wk at 13,17 or $21^{\circ} \mathrm{C}$ prior to thermal performance assays. Compared to limpets from the warm estuary site, limpets from the cold outer coast site had similar foot muscle critical thermal maxima $\left(\mathrm{CT}_{\max } ; 35.2\right.$ vs. $35.6^{\circ} \mathrm{C}$ ) but lower cardiac thermal tolerances (ABT: 30.5 vs. $35.1^{\circ} \mathrm{C}$ ). Limpets from the cold coast site had higher acclimation responses in foot muscle $\mathrm{CT}_{\max }$ $\left(0.22^{\circ} \mathrm{C}\right.$ per $1^{\circ} \mathrm{C}$ rise in acclimation) than those of the warm estuary site $\left(0.07^{\circ} \mathrm{C}\right.$ per $1^{\circ} \mathrm{C}$ rise in acclimation), but lower acclimation responses in cardiac thermal tolerance $\left(\mathrm{ABT}:-0.85^{\circ} \mathrm{C}\right.$ per $1^{\circ} \mathrm{C}$ rise in acclimation) than those of the estuary site (ABT: $0.10^{\circ} \mathrm{C}$ per $1^{\circ} \mathrm{C}$ rise in acclimation). Since outer coast populations had lower cardiac plasticity and higher mortalities in the warm acclimation, we predict $L$. limatula from colder habitats will be more susceptible to rising temperatures. Our findings illustrate the importance of population-specific variation in short-term thermal plasticity when considering the effects of climate change on ectotherms.
\end{abstract}

KEY WORDS: Intertidal · Ectotherm · Thermal tolerance $\cdot$ Plasticity $\cdot$ Acclimation $\cdot$ Ecophysiology

\section{INTRODUCTION}

Since the effects of temperature are pervasive on many levels of biological organization (Somero 1997), thermal gradients are strong determinants of species distributions (Badgley \& Fox 2000, Lo Presti \&

${ }^{*}$ Corresponding author: twangs@berkeley.edu
Oberprieler 2009). In intertidal ectotherms, thermal tolerances are thought to be adapted to their maximal habitat temperatures (Tomanek \& Somero 1999, Morley et al. 2009, Zippay \& Hofmann 2010). Upper thermal tolerance limits have been shown to generally decrease with latitude; i.e. species living closer

(C) The authors 2019. Open Access under Creative Commons by Attribution Licence. Use, distribution and reproduction are unrestricted. Authors and original publication must be credited. 
to the equator are more capable of withstanding heat (Sunday et al. 2011). However, macrophysiological patterns do not occur latitudinally in intertidal zone species that experience mosaic patterns of habitat temperature maxima due to local topography and timing of tides (Helmuth et al. 2006, Kuo \& Sanford 2009). Interspecific variation of upper thermal tolerance and plasticity has been well documented in intertidal ectotherms, but we lack a clear consensus on general patterns of intraspecific variation. In copepods, crabs, and snails, populations of one species from warmer and drier climates have been shown to have higher thermal tolerance (Willett 2010, Madeira et al. 2012, Gleason \& Burton 2015). However, not all species show correlated environmental and physiological variation; for example, the intertidal snails Littorina keenae and Crepidula fornicata show weak to no evidence of latitudinal cline in thermal tolerance (Lee \& Boulding 2010, Diederich $\&$ Pechenik 2013). The degree to which adaptation over local habitat temperature gradients reflects macrophysiological patterns is important to understand in the context of predicting responses to environmental change.

In cases where species have small thermal safety margins (i.e. thermal tolerance limits are close to maximal habitat temperatures), the plasticity of thermal tolerance is a secondary important determinant of response to habitat warming (Gunderson \& Stillman 2015). In environments of rising temperatures, thermal plasticity is a strategy to cope with increased temperatures; as an organism acclimates to a higher temperature, its upper thermal tolerances can increase in response (Pörtner et al. 2006). For example, species can undergo heat-hardening transiently adjusting their upper thermal limits through heatshock responses (Dahlhoff \& Somero 1993, Hamdoun et al. 2003). Several hypotheses serve to explain macrophysiological variation in plasticity of thermal tolerance. The latitudinal hypothesis predicts that species living at higher latitudes have higher potentials of thermal plasticity in order to withstand seasonality and fluctuating temperatures (Janzen 1967, Levins 1968, Gabriel \& Lynch 1992, Bozinovic et al. 2011). The Brattstrom hypothesis predicts that widespread species with larger geographic ranges experience broader thermal environments, and thus have higher thermal tolerance plasticity (Brattstrom 1968, Spicer \& Gaston 2009). The trade-off hypothesis posits that species of higher thermal tolerances have smaller thermal safety margins and exhibit lower potentials of thermal plasticity (Tomanek \& Somero 1999, Tomanek \& Helmuth 2002, Stillman 2003, Sten- seng et al. 2005, Gunderson \& Stillman 2015, Armstrong et al. 2019). This suggests that species or populations with the highest upper thermal tolerances are most vulnerable to extirpation as a result of climate change (Stillman 2003). However, not all comparative studies have yielded support for these hypotheses. Calosi et al. (2008) found thermal tolerance to be positively correlated with tolerance plasticity in Deronectes diving beetles, and Simon et al. (2015) found no relationship between upper thermal tolerance and plasticity. The degree of thermal plasticity has been shown to depend on factors like thermoregulatory behavior, life stage, and evolutionary trajectory, further complicating our understanding of macrophysiological patterns (Marais et al. 2009, Bozinovic et al. 2011, Sheldon \& Tewksbury 2014, Gunderson \& Stillman 2015).

This study focused on the thermal limits and plasticity of those limits in the file limpet Lottia limatula (Carpenter, 1864) across thermally variable sites in northern California. L. limatula ranges from central Oregon to Baja California, where they inhabit the mid to low intertidal zones and graze microscopic algae (Lindberg 1981). The population is generally continuous in southern California, but north of Santa Cruz, L. limatula are only found in locations where water temperatures are warmer (Test 1945). For example, an isolated population, likely recruited from a southern population during a Southern Oscillation event (El Niño), resides within the inner Tomales Bay (Jacobs et al. 2004). This population was first named Lottia morchii by Dall (Dall, 1878). Like other intertidal limpets, range limits of $L$. limatula are in part constrained by stressful thermal environments (Miller et al. 2009, Fenberg \& Rivadeneira 2011).

The goals of this study were to explore variation in thermal physiology in L. limatula collected from sites where the species is likely to have experienced longterm differences in habitat temperatures. We hypothesized that upper thermal tolerances of L. limatula populations are positively correlated with their corresponding maximal habitat temperatures. Since there is a cost to maintaining plasticity for higher thermal tolerances (Kingsolver \& Huey 1998, Ernande \& Dieckmann 2004), selection can favor higher upper thermal tolerances and lower plasticity in cases of evolution to extreme heat (Chevin et al. 2010). A previous study on Tegula spp., a similar intertidal gastropod, found a negative relationship between upper thermal tolerance and its plasticity (Stenseng et al. 2005). Accordingly, we hypothesized that limpets with higher upper thermal tolerances have reduced plasticity of heat tolerance. 


\section{MATERIALS AND METHODS}

\subsection{Site selection}

Elkhorn Slough (36 80' 86" N, 121 $71^{\circ}$ ' 89" W), Inner Tomales Bay $\left(38^{\circ} 13^{\prime} 33^{\prime \prime} \mathrm{N}, 122^{\circ} 89^{\prime} 41^{\prime \prime} \mathrm{W}\right)$, and San Francisco Bay (SF Bay; 3789' 28" N, 122 44' 77" W) were chosen as the 3 collection sites (Fig. 1). Sites were chosen to best represent the range of environmental conditions to which Lottia limatula are exposed in northern California. Inner Tomales Bay (Marin County, California) is a small, shallow bay that experiences heavy seasonal temperature swings. This area also receives relatively warm freshwater influxes, creating a strong thermal and saline gradient between the inner and outer bay. Inner Tomales Bay and SF Bay were selected as warmer inland estuary sites, whereas Elkhorn Slough (Moss Landing, California) is closest to the outer coast and most exposed to the cold, marine regime.

\subsection{Site temperature}

Sea surface temperature (SST) and air temperature data (1 Jun 2016-30 Nov 2016) were downloaded from NOAA's National Estuarine Research Reserve System (NERRS) (http://cdmo.baruch.sc.edu/) and Coastal Observations and Monitoring Science (COMS) (http://coastalobservations.sfsu.edu), respectively. Tomales Bay SST data were collected and provided by

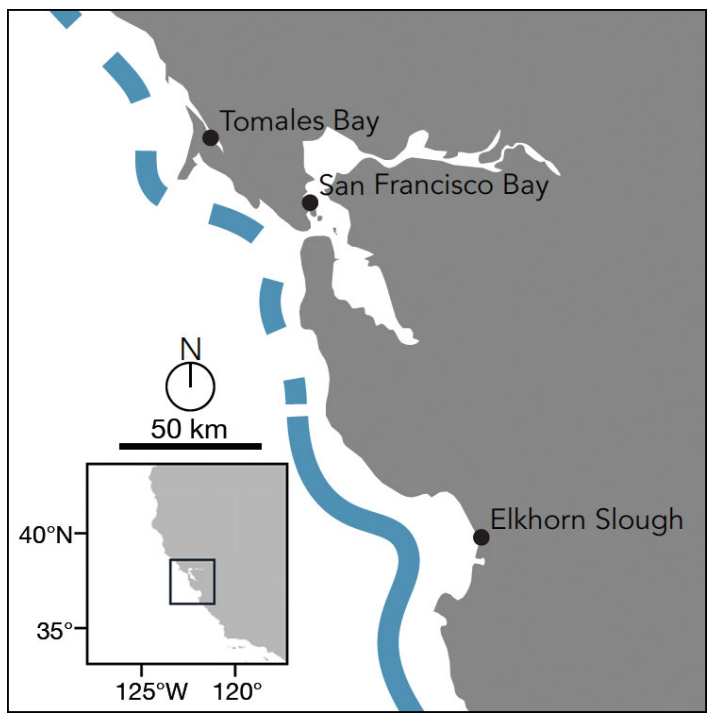

Fig. 1. Collection sites of limpets in northern California. Blue line: range of Lottia limatula; the population is generally continuous in southern California, but north of Santa Cruz, L. limatula are only found in locations where water temperatures are warmer (Test 1945) the Grosholz Lab at the University of California at Davis. Temperature data points were collected every 15 min and used as raw data for the following calculations. The 6 highest daily temperature maximums were used to represent the maximum for the summer (1 Jun 2016-31 Aug 2016) and fall (1 Sep 201630 Nov 2016) seasons. Seasonal variances were calculated by averaging the squared differences from the daily mean temperature. Annual variance was calculated from the year prior to limpet collection (15 Nov 2015-15 Nov 2016).

\subsection{Limpet collection and housing}

Adult L. limatula were sampled between mid-November and early December 2016 at mid-intertidal zones ( 0.6 $\mathrm{m}$ above mean lower low water) where they were most abundant. Limpets $(\mathrm{n}=66)$ were collected from each site (permit: CA DFW SCP-13357) and transported to the laboratory, where they were equally divided among flow-through seawater aquaria of 3 acclimation temperatures: $13 \pm 1,17 \pm 1$, and $21 \pm$ $1{ }^{\circ} \mathrm{C}$ and held for 14-16 d, which has been demonstrated as being long enough for limpets to achieve steady-state plasticity in physiological phenotypes (Bjelde et al. 2015, Khlebovich 2017). The first acclimation temperature, $13^{\circ} \mathrm{C}$, was based on the mean SST of the week of collection (15 Nov-22 Nov 2016; Elkhorn Slough: $13.5^{\circ} \mathrm{C}$; SF Bay: $15.3^{\circ} \mathrm{C}$; Tomales Bay: $12.2^{\circ} \mathrm{C}$ ). The $17^{\circ} \mathrm{C}$ acclimation represented maximal 2016 summer SST of inland estuary sites (1 Jun31 Aug 2016; Elkhorn Slough: $14.9^{\circ} \mathrm{C}$; SF Bay: $17.0^{\circ} \mathrm{C}$; Tomales Bay: $17.0^{\circ} \mathrm{C}$ ), and the $21^{\circ} \mathrm{C}$ acclimation represented future summer SST of those sites based on IPCC's RCP8.5 Scenario 2100 forecast $\left(+4^{\circ} \mathrm{C}\right.$ ) (IPCC 2014). Limpets from all 3 sites were kept in the same tank for each acclimation temperature, separated by site with enclosures, and provided algae-covered cobbles from their collection locations for food. Limpets were monitored daily and dead limpets were removed promptly. Salinity was maintained at $29.1 \pm 1.6 \mathrm{ppt}$.

L. limatula non-lethal upper thermal tolerance limits were evaluated using 3 metrics. These were foot muscle critical thermal maximum $\left(\mathrm{CT}_{\max }\right)$ and 2 metrics of cardiac thermal tolerance: Arrhenius break temperature (ABT) and flatline temperature (FLT).

\subsection{Foot muscle $\mathrm{CT}_{\max }$}

Foot muscle $\mathrm{CT}_{\max }$ was defined as the temperature at which the organism loses its neuromuscular ability 
to grasp a vertical surface. Fallen limpets are more susceptible to predation or being washed away by waves, which have negative fitness consequences (Marshall et al. 2015); thus, this is an ecologically important metric. Other studies on mollusks and limpets have referred to the temperature of neuromuscular failure or detachment from substratum as the onset of heat coma temperature (HCT) or non-lethal thermal tolerance (Clarke et al. 2000, Sokolova \& Pörtner 2003, Denny et al. 2006, Marshall et al. 2015, Miller et al. 2015, Chapperon et al. 2016). Limpets are known to use adhesive mucus to hold onto the substrate, but this strategy is primarily used during emersion in air (Smith 2002). Since limpets mostly use suction to grip onto surfaces just after moving (Smith et al. 1999), we were not concerned with mucus influencing our foot muscle $\mathrm{CT}_{\max }$ data. Foot muscle $\mathrm{CT}_{\max }$ was determined in limpets from Tomales Bay and Elkhorn Slough. We were unable to sample foot muscle $\mathrm{CT}_{\max }$ for SF Bay limpets due to experimental limitations. Limpets were gently attached pointing downward on the vertical walls of $150 \mathrm{ml}$ glass beakers filled with $100 \mathrm{ml}$ of air-saturated seawater; beakers were temperature-controlled in a recirculating water bath. Limpets rested at their acclimation temperatures for 30 min before the $+4^{\circ} \mathrm{C} \mathrm{h}^{-1}$ heat ramp commenced. Consistent with similar studies, the heat ramp rate was chosen based on a realistic environmental rate (Tomanek \& Somero 1999, Stenseng et al. 2005). Temperature inside the water bath was monitored using iButton thermochron dataloggers (Maxim Integrated $^{\mathrm{TM}}$ ). To determine foot muscle $\mathrm{CT}_{\max }$, the time when limpets lost grip and fell off the vertical wall was matched to the temperature at that time recorded by the nearest iButton.

\subsection{Cardiac thermal tolerance (ABT and FLT)}

Two cardiac thermal tolerance metrics were assessed: ABT and FLT. ABT was defined as the temperature at which heart rate sharply declined (Dahlhoff \& Somero 1993). We measured ABT to compare with other studies on cardiac thermal tolerances of mollusk and limpets (Stenseng et al. 2005, Bjelde et al. 2015, Drake et al. 2017). Since gastropods can survive well past their ABT, we recorded FLT, the temperature at which limpet hearts stopped beating (Stenseng et al. 2005, Polgar et al. 2015). Heart beats of limpets not used for foot $\mathrm{CT}_{\max }$ determination were monitored as described previously (Bjelde \& Todgham 2013, Bjelde et al. 2015). Between 18 and $24 \mathrm{~h}$ before heart rate monitoring, 2 holes, $2 \mathrm{~mm}$ in diameter, were drilled into both sides of the limpet shell apex. Limpets were immediately returned to their original tanks for recovery. An hour before the heat ramp, 2 electrodes, made with 40 gauge ceramic-coated copper wire, were inserted in the holes to surround either side of the limpet heart. Electrodes were firmly glued in place on the shell with cyanoacrylate glue (Bob Smith Industries). Limpets were individually placed in glass Petri dishes fitted in wells of an aluminum block circulated with a temperature-controlled programmable water bath set to the acclimation temperature (Lauda, Lauda-Königshofen). Glass dishes were filled with $25 \mathrm{ml}$ of seawater to completely immerse limpets. Impedance between the 2 electrodes was converted into voltage by UFI 2991 Impedance Converters and recorded with a PowerLab (ADInstruments) using LabChart 5 software (ADInstruments). Limpets rested for $30 \mathrm{~min}$ at their acclimation temperatures before $+4^{\circ} \mathrm{C} \mathrm{h}^{-1}$ heat ramps commenced. Heat ramps ran until limpet hearts stopped beating for 15 min. Heart rates (beats $\mathrm{min}^{-1}$ ) and temperatures were averaged over consecutive $30 \mathrm{~s}$ intervals.

To measure ABT, Arrhenius plots were created by plotting the natural log of heart rates versus inverse temperatures $\left(1000 \mathrm{~K}^{-1}\right)$. Robust linear regressions were fitted to the data before and after the sharpest inflection in the slope of heart rate using the 'robustbase' package (Maechler et al. 2019) in R v.3.2.4 (R Core Team 2016). The ABT was defined as the temperature at which the 2 regression lines intersect (Figs. S1 to S3 in the Supplement at www.int-res.com/ articles/suppl/b028p113_supp.pdf). FLT was determined as the temperature at which the limpet heart stopped beating.

Once the heat ramps were completed, limpets were removed from their shells and dried for $48 \mathrm{~h}$ at room temperature. Dry body mass and shell mass (epibiota were removed) were determined to the nearest $0.01 \mathrm{~g}$ on an analytical balance (Mettler-Toledo).

\subsection{Statistical analyses}

We used a multi-model inference approach to estimate the proportion of limpet deaths during acclimation treatments and explore which variables most related to mortality (Zuur et al. 2009, Symonds \& Moussalli 2011). In the 'nlme' package (Pinheiro et al. 2019), a full logistic regression model was run with binary outcome data (death:1, alive:0) as our response variable, and the following predictor variables as fixed effects: site, acclimation, and their interaction. Assumptions of normality, no multicollinearity, and 
homogeneity of variances were met. A series of models representing all possible combinations of predictor variables was generated and subsequently compared to the full model using Akaike's Information Criterion (AIC), which is a measure of fit with a penalty on overfitting. Weights based on AIC were assigned to each model. A weighted averaged model was calculated from the set of top-ranked models, whose cumulative AIC weights were $\leq 0.95$, by averaging the parameter estimates in the 'MuMIN' package (Barton 2019).

The 2 hypotheses - limpet $\mathrm{CT}_{\max }$ is positively correlated with their maximum habitat temperatures and limpets with higher $\mathrm{CT}_{\max }$ have reduced plasticity - were separately evaluated for each metric (foot muscle $\mathrm{CT}_{\max }, \mathrm{ABT}$, and FLT). A multi-model inference approach, similar to the one described before, was used to predict means of each acclimation-site group and explore which variables most related to $\mathrm{CT}_{\text {max }}$. Generalized least squares models were run with $\mathrm{CT}_{\max }$ as the response variable and the following predictor variables as fixed effects: site, acclimation temperature treatment, dry body weight, and their interactions. Number of ABTs was included as an additional predictor variable for ABT and FLT analyses because Lottia sp. have been previously documented to have multiple ABTs, which could result from active depression of heart rate in order to conserve energy during heat stress (Bjelde et al. 2015, Bjelde \& Todgham 2013). Since we recorded limpets with only 1 or 2 ABTs, proportions of limpets with 2 ABTs were analyzed with a separate binomial logistic regression analysis. Assumptions of normality and homogeneity of variances were met using variance structures fixed along dry weight (variance of $\mathrm{CT}_{\max }$ was proportional to dry weight). A linear regression between shell weight and dry body weight revealed that they were strongly collinear (Fig. 2). Thus, shell weight was dropped from our analysis, and dry body weight was chosen as the better variable representing limpet body mass. A weighted averaged model was calculated from the set of top-ranked models (cumulative sum $\leq 0.95$ ) using $\mathrm{AIC}_{\mathrm{C}}$ a version of AIC for small sample sizes. Site coefficients of the weighted averaged models were compared to explore the effects of site on $\mathrm{CT}_{\text {max }}$. Coefficients of the interactions between site and acclimation were compared to explore differences of plasticity among sites.

Elkhorn Slough and SF Bay limpets tended to be larger than Tomales Bay limpets (Fig. S4 in the Supplement). Linear regressions were performed between dry body weight and $\mathrm{CT}_{\max }$ metrics to determine if there was a general trend between body size and thermal tolerance for $L$. limatula. Dry body

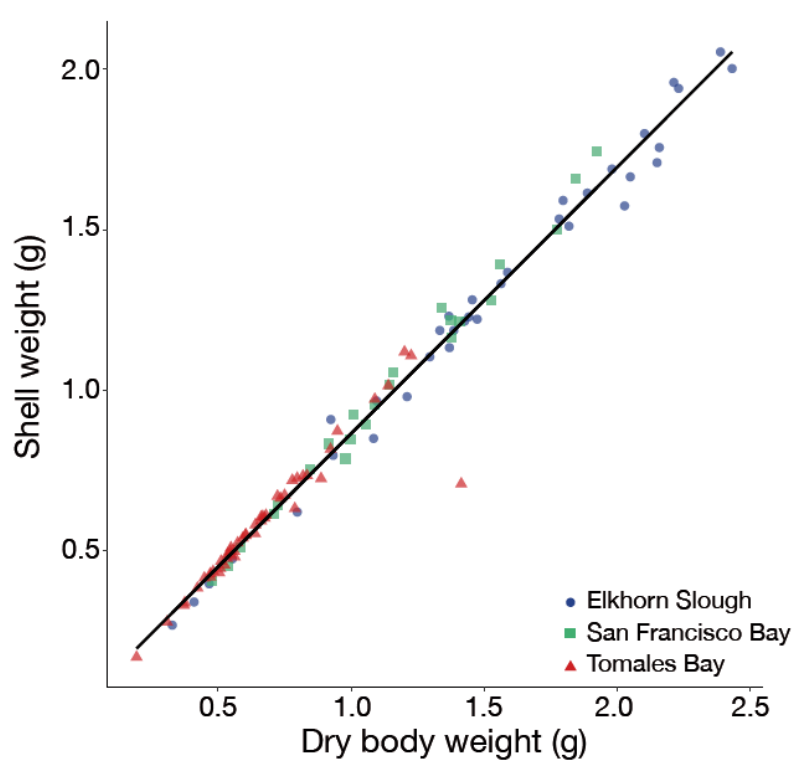

Fig. 2. Linear regression between shell weight and dry body weight of Lottia limatula (slope $=0.83, F_{1,103}=5141, \mathrm{p}<0.001$, $\left.\mathrm{r}^{2}=0.98\right)$

weight and site were found to be confounding variables for ABT and FLT. In order to evaluate the effects of site on ABT and FLT more confidently, the multi-model inference analyses were performed again on a subset of limpets with dry body weights between 1.0 and $2.0 \mathrm{~g}$. This additional multi-model inference analysis used linear regressions with no variance structure and did not include dry body weight as a predictor variable.

Plasticity of limpets was additionally compared using the acclimation response ratio (ARR), the slope of the line describing the $\mathrm{CT}_{\max }$ change based on the acclimation temperature difference (Claussen 1977, Gunderson \& Stillman 2015). An ARR of 1 means that limpets increased their $\mathrm{CT}_{\max }$ by $1^{\circ} \mathrm{C}$ for every $1^{\circ} \mathrm{C}$ rise in acclimation temperature. For each site and $\mathrm{CT}_{\max }$ metric group, ARR was defined as the slope of the linear regression of all $\mathrm{CT}_{\max }$ points collected between 13 and $21^{\circ} \mathrm{C}$ acclimation temperatures. Likelihood-ratio tests comparing the goodness-of-fit between the null and alternative models were used to further evaluate the hypothesis that limpets of higher $\mathrm{CT}_{\max }$ have reduced plasticity (see Methods in the Supplement).

\section{RESULTS}

\subsection{Site temperature}

Compared to the other 2 sites, the Elkhorn Slough site had lower $\operatorname{SST}\left(18.4^{\circ} \mathrm{C}\right)$ and air temperature 
Table 1. Maximum summer (1 Jun-31 Aug 2016) and fall (1 Sep-30 Nov 2016) air and sea surface temperatures (SST) at the 3 Lottia limatula collection sites. Air and SSTs were averaged daily; variances of each season were calculated by averaging the squared differences from the mean; annual variance was calculated from the year prior to limpet collection (15 Nov 201515 Nov 2016). SF Bay: San Francisco Bay; ND: no data

\begin{tabular}{|c|c|c|c|c|c|c|c|c|c|c|}
\hline \multirow{2}{*}{ Site } & \multicolumn{5}{|c|}{ SST } & \multicolumn{5}{|c|}{ Air } \\
\hline & $\begin{array}{l}\text { Summer } \\
\max \text {. } \\
\left({ }^{\circ} \mathrm{C}\right)\end{array}$ & $\begin{array}{c}\text { Summer } \\
\text { variance } \\
\left({ }^{\circ} \mathrm{C}^{2}\right)\end{array}$ & $\begin{array}{l}\text { Fall } \\
\max . \\
\left({ }^{\circ} \mathrm{C}\right)\end{array}$ & $\begin{array}{c}\text { Fall } \\
\text { variance } \\
\left({ }^{\circ} \mathrm{C}^{2}\right)\end{array}$ & $\begin{array}{c}\text { Annual } \\
\text { variance } \\
\left({ }^{\circ} \mathrm{C}^{2}\right)\end{array}$ & $\begin{array}{l}\text { Summer } \\
\max \text {. } \\
\left({ }^{\circ} \mathrm{C}\right)\end{array}$ & $\begin{array}{c}\text { Summer } \\
\text { variance } \\
\left({ }^{\circ} \mathrm{C}^{2}\right)\end{array}$ & $\begin{array}{l}\text { Fall } \\
\max . \\
\left({ }^{\circ} \mathrm{C}\right)\end{array}$ & $\begin{array}{c}\text { Fall } \\
\text { variance } \\
\left({ }^{\circ} \mathrm{C}^{2}\right)\end{array}$ & $\begin{array}{c}\text { Annual } \\
\text { variance } \\
\left({ }^{\circ} \mathrm{C}^{2}\right)\end{array}$ \\
\hline Elkhorn Slough & 18.4 & 0.5 & 19.1 & 0.8 & 0.9 & 22.5 & 1.1 & 31.0 & 5.0 & 5.7 \\
\hline SF Bay & 19.6 & 0.3 & 19.2 & 0.8 & 4.4 & 28.6 & 2.1 & 32.3 & 7.8 & 8.1 \\
\hline Tomales Bay & 22.5 & 0.2 & 19.1 & 3.4 & 4.4 & ND & ND & ND & ND & ND \\
\hline
\end{tabular}

$\left(22.5^{\circ} \mathrm{C}\right)$ maxima for summer (Table 1). Of the 3 sites, Tomales Bay had the highest summer maxima for SST

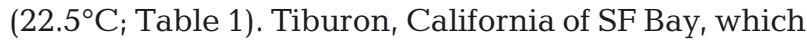
latitudinally lies between Tomales Bay and Elkhorn Slough, had a moderate climate and summer SST maxima $\left(19.6^{\circ} \mathrm{C}\right)$. Inner Tomales Bay SST had the greatest variability in temperature (annual variance: $4.4^{\circ} \mathrm{C}^{2}$; fall variance: $3.4^{\circ} \mathrm{C}^{2}$ ), Tiburon SST had moderate variability (annual variance: $4.4^{\circ} \mathrm{C}^{2}$; fall variance: $0.8^{\circ} \mathrm{C}^{2}$ ), and Elkhorn Slough SST had the least variability (annual variance: $0.9^{\circ} \mathrm{C}^{2}$; fall variance: $0.8^{\circ} \mathrm{C}^{2}$ ).

\subsection{Mortality}

Mortality, or the binomial probability of death, in limpets from all sites and at all acclimation conditions was best explained by 2 model predictions that had $\Delta$ AIC $<2$. The top-ranked model included acclimation and site as predictor variables while the second-best model included acclimation, site, and their interaction as predictor variables $(\triangle \mathrm{AIC}=1.8)$. Averaged, this model (Table $2, \Delta \mathrm{AIC}=0.5$ ) was strongly influenced

Table 2. Full averaged-models results of binomial Lottia limatula mortality data, with $13^{\circ} \mathrm{C}$ acclimation (Acc), Elkhorn Slough site, and their interactions as the intercept. SF Bay: San Francisco Bay. Statistically significant variables are in bold text

\begin{tabular}{|lrrrr|}
\hline Variable & Estimate & SE & $z$-value & p-value \\
\hline Intercept & -2.21 & 0.89 & 2.48 & $<0.05$ \\
$17^{\circ} \mathrm{C}$ Acc & 1.27 & 0.94 & 1.34 & 0.18 \\
$\mathbf{2 1}{ }^{\circ} \mathbf{C}$ Acc & $\mathbf{2 . 8 6}$ & $\mathbf{1 . 0 9}$ & $\mathbf{2 . 6 3}$ & $<\mathbf{0 . 0 1}$ \\
SF Bay & -0.35 & 1.06 & 0.33 & 0.74 \\
Tomales & -0.99 & 1.40 & 0.70 & 0.48 \\
$17^{\circ} \mathrm{C}$ Acc $\times$ SF Bay & -0.38 & 0.99 & 0.39 & 0.70 \\
$21^{\circ} \mathrm{C}$ Acc $\times$ SF Bay & -0.69 & 1.31 & 0.53 & 0.60 \\
$17^{\circ} \mathrm{C}$ Acc $\times$ Tomales & -0.85 & 1.59 & 0.53 & 0.59 \\
$21^{\circ} \mathrm{C}$ Acc $\times$ Tomales & -0.98 & 1.69 & 0.58 & 0.56 \\
\hline
\end{tabular}

by the $21^{\circ} \mathrm{C}$ acclimation condition. At $21^{\circ} \mathrm{C}$, mortality was significantly higher than at the 2 other acclimation temperatures, with Elkhorn Slough limpets experiencing the largest increase in mortality (Fig. 3). Overall, Tomales Bay had the lowest mortality rates across acclimation conditions (Tomales Bay mortality: 0.11; SF Bay: 0.21; Elkhorn Slough: 0.35). Site effects were not statistically significant in the averaged model; however, their inclusion in the 2 separate top model predictions is important to note for future studies.

\section{3. $\mathrm{CT}_{\max }$ of foot muscle}

Mean foot muscle $\mathrm{CT}_{\max }$ ranged from 35 to $37.5^{\circ} \mathrm{C}$ across locations and acclimation conditions, with highest values occurring under warmer acclimation conditions (Fig. 4A). The foot muscle $\mathrm{CT}_{\max }$ of Tomales Bay

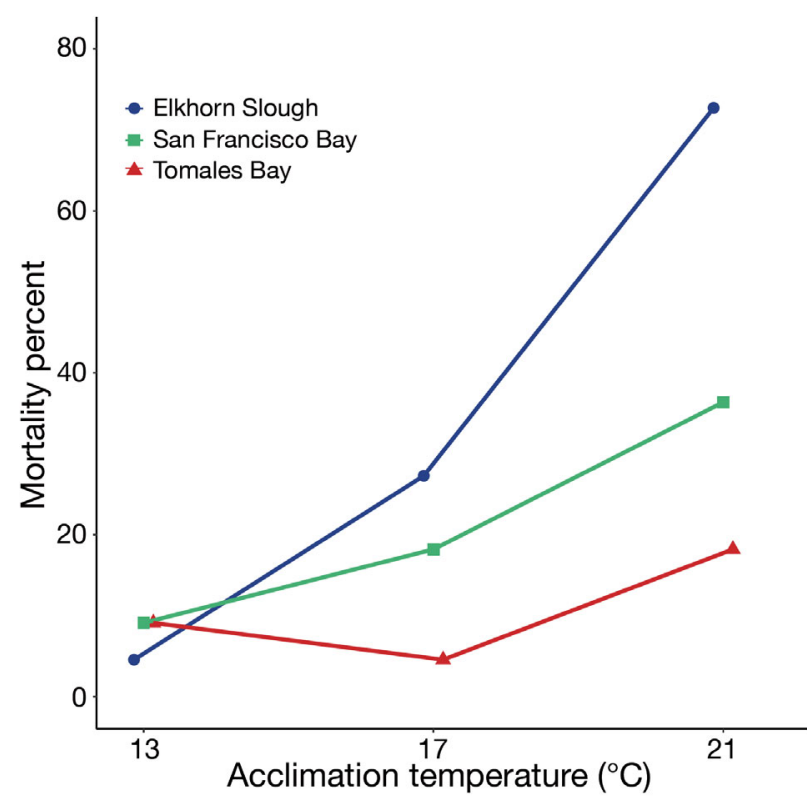

Fig. 3. Limpets from different collection sites varied in their survival across acclimation temperatures 

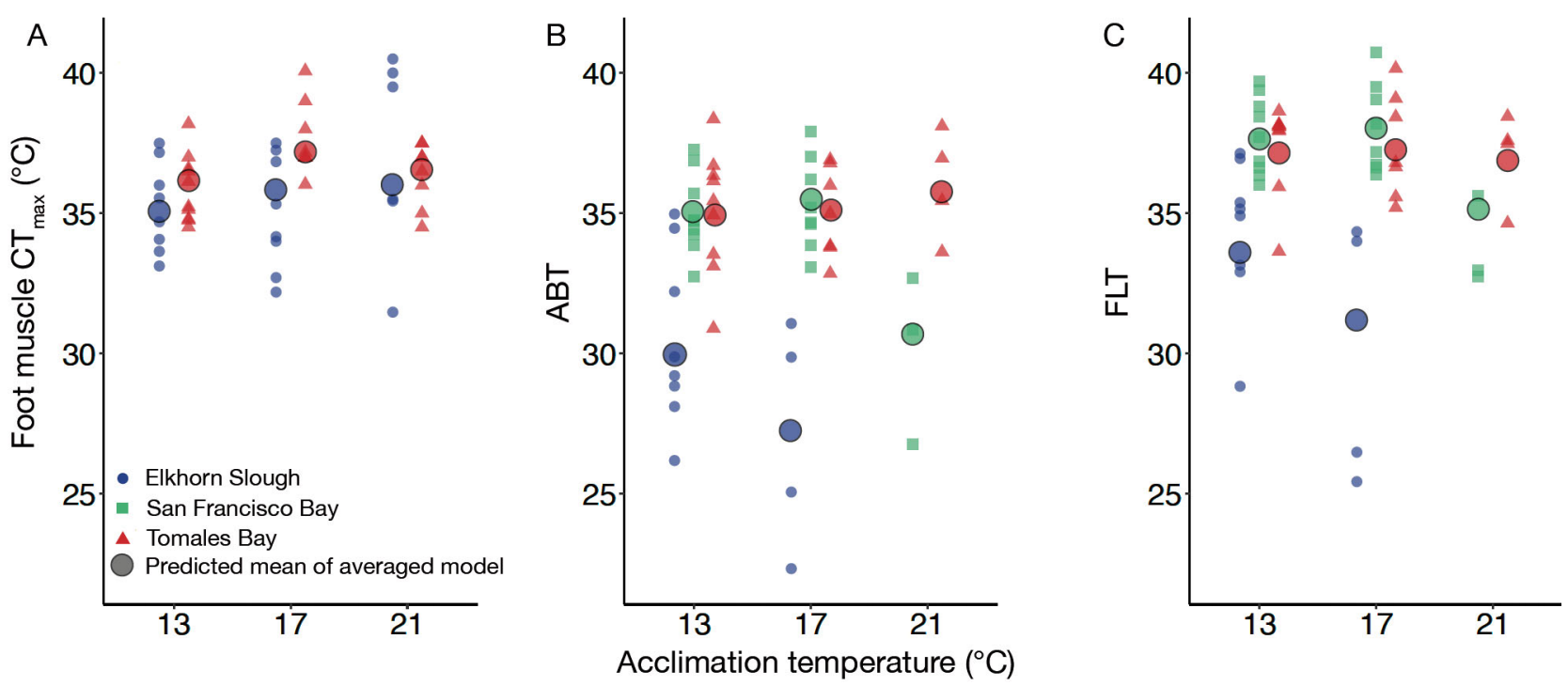

Fig. 4. (A) Foot muscle critical thermal maxima $\left(\mathrm{CT}_{\max }\right)$, (B) Cardiac Arrhenius breakpoint temperature (ABT), and (C) cardiac flatline temperature (FLT) of Lottia limatula subjected to heat ramps of $+4^{\circ} \mathrm{C} \mathrm{h}^{-1}$. Smaller symbols: individual limpets; larger circles: averaged models' predicted means of treatment groups

limpets was $2.7^{\circ} \mathrm{C}$ higher than Elkhorn Slough limpets in $17^{\circ} \mathrm{C}$-acclimated specimens (Fig. $4 \mathrm{~A}$ ); at 13 and $21^{\circ} \mathrm{C}$ acclimation temperatures there were no differences between populations. Variance of Tomales Bay limpets' foot muscle $\mathrm{CT}_{\max }$ remained consistently low across the 3 acclimation temperatures, while the variance of Elkhorn Slough foot muscle $\mathrm{CT}_{\max }$ increased with acclimation temperature (Fig. 4A). Since the predictor variables of acclimation, site, and their interaction did not have statistically significant estimates in the averaged model (Table 3A), they did not have any effect on foot muscle $\mathrm{CT}_{\max }$. Since site did not have an effect on foot muscle $\mathrm{CT}_{\max }$, these results did not support the hypothesis that limpet foot muscle $\mathrm{CT}_{\max }$ is positively correlated with their maximum habitat temperatures. There was no relationship between foot muscle $\mathrm{CT}_{\max }$ and dry body weight (Fig. 5A).

Tomales Bay limpets had lower foot muscle $\mathrm{CT}_{\max }$ plasticity compared to Elkhorn Slough limpets (ARR: $0.07 \pm 0.08$ vs. $0.22 \pm 0.16^{\circ} \mathrm{C}$ per $1{ }^{\circ} \mathrm{C}$ rise in acclimation, respectively). We expected an interaction between site and acclimation temperature on foot muscle $\mathrm{CT}_{\max }$ in the statistical model. However, none of the predictor variables had statistically significant effects (Table 3A), indicating that foot muscle $\mathrm{CT}_{\max }$ plasticity was not statistically different between Tomales Bay and Elkhorn Slough limpets. These results also did not support the hypothesis that limpets with higher foot muscle $\mathrm{CT}_{\max }$ have lower plasticity (Table 2A); likelihood-ratio test results also supported these findings (see supplemental Results and Tables S1 \& S2A in the Supplement).

\subsection{ABT}

Mean cardiac ABTs ranged from 27 to $36^{\circ} \mathrm{C}$ in limpets from across acclimation temperatures and collection sites (Fig. 4B). Limpets from Elkhorn Slough had 5 and $8^{\circ} \mathrm{C}$ lower ABTs than limpets from the other 2 sites at 13 and $17^{\circ} \mathrm{C}$ acclimation temperatures, respectively (Fig. 4B). Acclimation to $21^{\circ} \mathrm{C}$ reduced $\mathrm{ABT}$ of SF Bay limpets by about $5^{\circ} \mathrm{C}$, whereas $\mathrm{ABT}$ of Tomales Bay limpets was unaffected and remained close to values at 13 and $17^{\circ} \mathrm{C}$ acclimation temperatures (Fig. 4B). The averaged model predicted similar mean results to the observed arithmetic means (on average the absolute difference was only $0.24^{\circ} \mathrm{C}$ ) for all 3 acclimation temperatures (Fig. 4B). The averaged model showed that site had strong positive effects on $\mathrm{ABT}$, and confirmed that the higher ABTs in Tomales Bay and SF Bay limpets were statistically significant (Table 3B). Since both Tomales Bay and SF Bay sites had higher summer maximum temperatures than Elkhorn Slough, these results partially supported our first hypothesis that limpet ABTs are positively correlated with their maximum habitat temperatures. Based on their high p-values, number of ABTs, dry weight, and their interactions had little relation to ABT (Table 3B). A binomial logistic regression revealed that the proportion of limpets with 2 ABTs did not have a statistically significant relationship $(p>0.05)$ with site, acclimation treatment, or their interactions (Fig. S5 in the Supplement). 
Table 3. Full averaged-models results of 3 metrics of Lottia limatula heat tolerance. (A) Foot muscle $\mathrm{CT}_{\max }: 13^{\circ} \mathrm{C}$ acclimation (Acc), the Elkhorn Slough site, and their interactions as the intercept; (B) Arrhenius breakpoint temperature (ABT): $13^{\circ} \mathrm{C}$ acclimation, Elkhorn Slough site, $1 \mathrm{ABT}$, their interactions with other variables, and $21^{\circ} \mathrm{C} \mathrm{Acc} \times \mathrm{SF}$ Bay as the intercept (there were no $21^{\circ} \mathrm{C}$-acclimated Elkhorn Slough limpets sampled for ABT); (C) flatline temperature (FLT): $13^{\circ} \mathrm{C}$ acclimation, Elkhorn Slough site, 1 ABT, their interactions with other variables, and $21^{\circ} \mathrm{C}$ Acc $\times$ SF Bay as the intercept (there were no $21^{\circ} \mathrm{C}$-acclimated Elkhorn Slough limpets sampled for FLT). Statistically significant predictor variable estimates are in bold text

\begin{tabular}{|c|c|c|c|c|}
\hline Variable & Estimate & SE & $z$-value & p-value \\
\hline \multicolumn{5}{|l|}{ (A) Foot muscle $\mathrm{CT}_{\max }$} \\
\hline Intercept & 34.39 & 1.16 & 28.97 & $<0.001$ \\
\hline $17^{\circ} \mathrm{C} \mathrm{ACC}$ & 2.20 & 1.55 & 1.39 & 0.16 \\
\hline $21^{\circ} \mathrm{C} \mathrm{AcC}$ & -0.26 & 1.09 & 0.23 & 0.81 \\
\hline Dry weight & 0.78 & 0.84 & 0.90 & 0.36 \\
\hline Tomales & 2.46 & 2.06 & 1.18 & 0.24 \\
\hline $17^{\circ} \mathrm{C}$ Acc $\times$ dry weight & -1.58 & 1.17 & 1.32 & 0.19 \\
\hline $21^{\circ} \mathrm{C}$ Acc $\times$ dry weight & 0.93 & 1.01 & 0.89 & 0.37 \\
\hline Tomales $\times$ dry weight & -2.13 & 2.06 & 1.02 & 0.30 \\
\hline \multicolumn{5}{|l|}{ (B) $\mathrm{ABT}$} \\
\hline Intercept & 26.59 & 2.31 & 11.34 & $<0.001$ \\
\hline $17^{\circ} \mathrm{C} \mathrm{ACC}$ & -0.85 & 4.40 & 0.19 & 0.84 \\
\hline $21^{\circ} \mathrm{C} \mathrm{Acc}$ & 3.18 & 8.05 & 0.39 & 0.69 \\
\hline Dry weight & 2.89 & 2.35 & 1.22 & 0.22 \\
\hline SF Bay & 8.18 & 3.60 & 2.26 & 0.02 \\
\hline Tomales & 7.12 & 2.32 & 3.01 & 0.003 \\
\hline $17^{\circ} \mathrm{C}$ Acc $\times$ dry weight & -1.92 & 2.70 & 0.71 & 0.48 \\
\hline $21^{\circ} \mathrm{C}$ Acc $\times$ dry weight & -0.39 & 6.16 & 0.06 & 0.95 \\
\hline $17^{\circ} \mathrm{C}$ Acc $\times$ SF Bay & 2.69 & 2.59 & 0.99 & 0.32 \\
\hline $21^{\circ} \mathrm{C}$ Acc $\times$ Tomales & 6.60 & 4.41 & 1.58 & 0.14 \\
\hline $17^{\circ} \mathrm{C}$ Acc $\times$ Tomales & 2.04 & 2.91 & 0.69 & 0.49 \\
\hline ABT Number & -0.68 & 1.31 & 0.52 & 0.60 \\
\hline $17^{\circ} \mathrm{C}$ Acc $\times$ ABT number & 0.90 & 1.72 & 0.52 & 0.60 \\
\hline $21^{\circ} \mathrm{C}$ Acc $\times$ ABT number & -1.48 & 4.3 & 0.34 & 0.74 \\
\hline Dry weight × SF Bay & -1.95 & 3.11 & 0.62 & 0.53 \\
\hline Dry weight $\times$ Tomales & -0.86 & 2.31 & 0.37 & 0.72 \\
\hline \multicolumn{5}{|l|}{ (C) FLT } \\
\hline Intercept & 32.57 & 1.53 & 20.90 & $<0.001$ \\
\hline SF Bay & 5.03 & 1.75 & 2.83 & $<0.01$ \\
\hline Tomales & 3.68 & 1.71 & 2.12 & 0.03 \\
\hline $17^{\circ} \mathrm{C} \mathrm{AcC}$ & -2.24 & 2.80 & 0.80 & 0.42 \\
\hline $21^{\circ} \mathrm{C} \mathrm{Acc}$ & 1.43 & 5.00 & 0.28 & 0.78 \\
\hline Dry weight & 0.94 & 1.34 & 0.70 & 0.48 \\
\hline $17^{\circ} \mathrm{C}$ Acc $\times$ SF Bay & 2.59 & 2.82 & 0.91 & 0.36 \\
\hline $21^{\circ} \mathrm{C}$ Acc $\times$ Tomales & 2.52 & 2.79 & 0.90 & 0.37 \\
\hline $17^{\circ} \mathrm{C} \mathrm{Acc} \times$ Tomales & 2.48 & 2.72 & 0.90 & 0.37 \\
\hline $\mathrm{ABT}$ number & -0.32 & 1.10 & 0.29 & 0.77 \\
\hline $17^{\circ} \mathrm{C}$ Acc $\times$ ABT number & 0.27 & 0.96 & 0.28 & 0.78 \\
\hline $21^{\circ} \mathrm{C}$ Acc $\times$ ABT number & -0.62 & 2.66 & 0.23 & 0.82 \\
\hline $17^{\circ} \mathrm{C}$ Acc $\times$ dry weight & -0.39 & 1.30 & 0.28 & 0.78 \\
\hline $21^{\circ} \mathrm{C}$ Acc $\times$ dry weight & -1.00 & 3.53 & 0.28 & 0.78 \\
\hline Dry weight $\times$ SF Bay & -0.39 & 1.22 & 0.32 & 0.75 \\
\hline Dry weight $\times$ Tomales & 0.57 & 1.66 & 0.34 & 0.74 \\
\hline $\mathrm{ABT}$ number $\times$ SF Bay & -0.21 & 1.01 & 0.21 & 0.83 \\
\hline ABT number $\times$ Tomales & -0.20 & 0.91 & 0.22 & 0.83 \\
\hline
\end{tabular}

Though there was a general statistically significant decline in ABT with increasing dry weight (Fig. 5B; $\left.F_{1,50}=4.62, \mathrm{p}<0.05, \mathrm{r}^{2}=0.08\right)$, the averaged model for limpets between 1.0 and $2.0 \mathrm{~g}$ confirmed that Elkhorn Slough limpets had lower ABTs despite differences in mass among sites (Table S3A in the Supplement). ABT plasticity was highest in Tomales Bay limpets (ARR: $0.10 \pm 0.14^{\circ} \mathrm{C}$ per $1^{\circ} \mathrm{C}$ rise in acclimation), and was negative in limpets from SF Bay $\left(-0.44 \pm 0.17^{\circ} \mathrm{C}\right.$ per $1^{\circ} \mathrm{C}$ rise in acclimation) and Elkhorn Slough $\left(-0.85 \pm 0.52^{\circ} \mathrm{C}\right.$ per $1^{\circ} \mathrm{C}$ rise in acclimation), suggesting that the warmer acclimation temperatures were beyond the thermal optima for those limpets. The full averaged model showed that the interaction between acclimation temperature and site did not have a statistically significant effect on ABT (Table 3B); however, likelihood-ratio tests showed that the ABT acclimation responses in limpets from Tomales Bay and SF Bay were statistically significantly more positive than in limpets from Elkhorn Slough (Table S2B). Since Tomales Bay limpets had the highest ABT and the largest positive ABT acclimation response, these results contradicted our second hypothesis that limpets with higher ABT have lower plasticity.

\subsection{FLT}

Mean FLTs were generally higher than ABTs, ranging from 30 to $38^{\circ} \mathrm{C}$ in limpets from across acclimation temperatures and collection sites (Fig. 4C). The same pattern across acclimation temperatures and collection sites was observed for FLT as was observed in

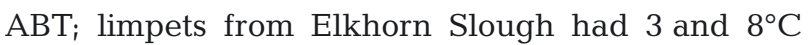
lower FLTs than the other 2 sites at 13 and $17^{\circ} \mathrm{C}$ acclimation temperatures, respectively (Fig. 4C). Acclimation to $21^{\circ} \mathrm{C}$ reduced the FLT of limpets from SF Bay by $4^{\circ} \mathrm{C}$, but did not affect the FLT of limpets from Tomales Bay (Fig. 4C). Similar to ABT results, the averaged model fit predicted similar FLT means to the observed arithmetic means (on average the absolute difference was only $0.42^{\circ} \mathrm{C}$ ) for all 3 acclimations (Fig. 4C). There was a strong effect of collection site on FLTs in the averaged model (Table 3C), confirming that FLTs of Tomales Bay and SF Bay limpets were statistically higher than that of Elkhorn Slough limpets. Since both Tomales Bay and SF Bay sites had higher summer maximums than the Elkhorn Slough site, these results partially support our first hypothesis that limpet FLTs are positively correlated with their maximum habitat temperatures. The number of ABTs, dry weight, and their interactions had little relation to FLT (Table 3C). 

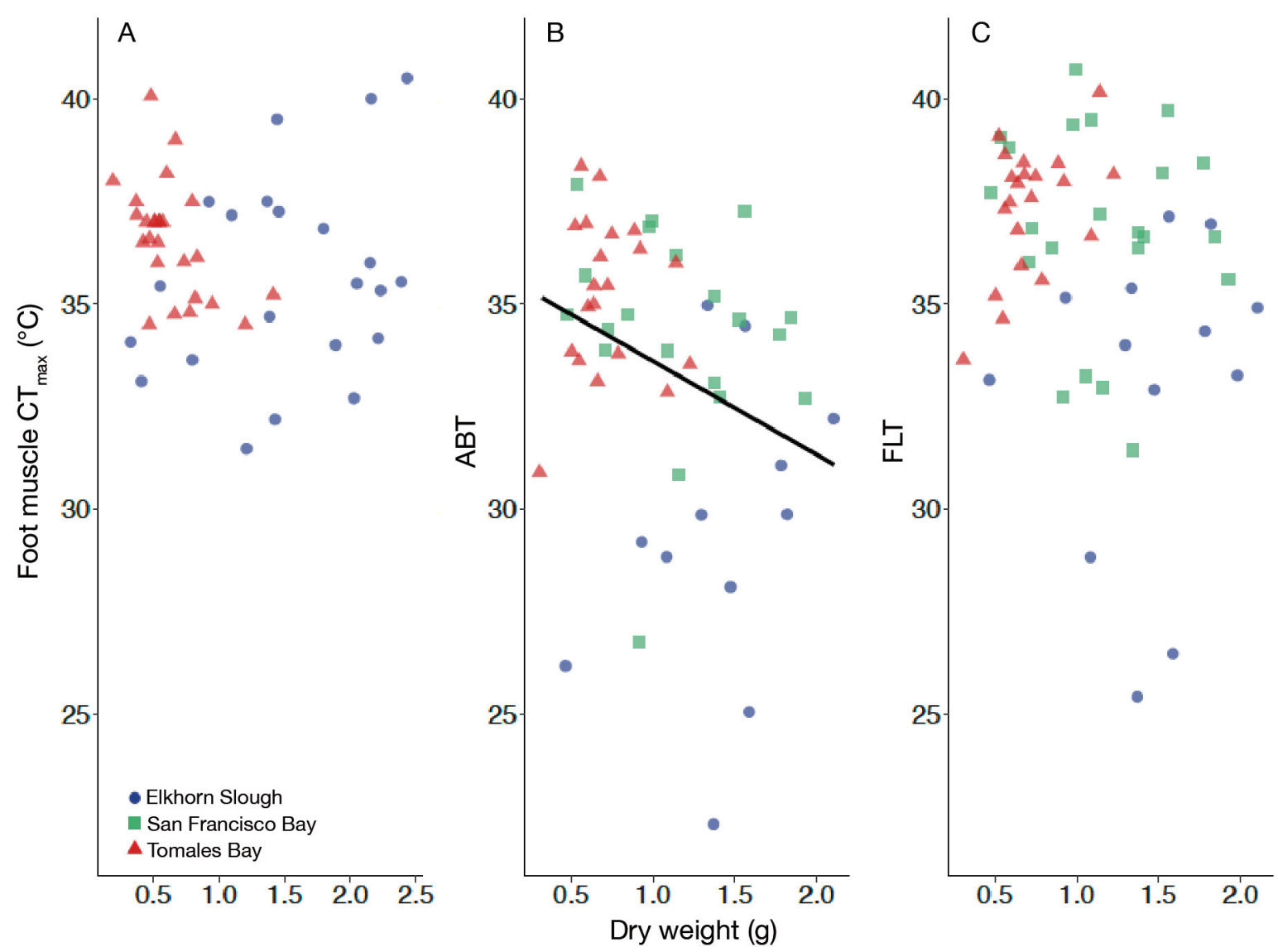

Fig. 5. (A) Foot muscle critical thermal maxima $\left(\mathrm{CT}_{\max }\right)$, (B) Cardiac Arrhenius breakpoint temperature (ABT), and (C) cardiac flatline temperature (FLT) of Lottia limatula plotted against dry body weight. Only the linear regression between ABT and dry weight was statistically significant $\left(F_{1,50}=4.62, \mathrm{p}<0.05, \mathrm{r}^{2}=0.08\right)$

There was no statistically significant trend between FLT and dry weight (Fig. 5C). An averaged model restricted to limpets of 1.0-2.0 g body mass revealed that limpets from Elkhorn Slough had lower FLTs despite differences in mass among sites (Table S3B).

Plasticity of FLTs followed a similar pattern to plasticity of ABTs; limpets from Tomales Bay had the highest positive FLT plasticity $\left(-0.03 \pm 0.12^{\circ} \mathrm{C}\right.$ per $1{ }^{\circ} \mathrm{C}$ rise in acclimation), and FLT plasticity was negative in limpets from SF Bay and Elkhorn Slough $\left(-0.50 \pm 0.13\right.$ and $-1.03 \pm 0.49^{\circ} \mathrm{C}$ per $1{ }^{\circ} \mathrm{C}$ rise in acclimation, respectively), following what was observed for ABT. The averaged model indicated that site, but not acclimation temperature, had a positive effect on FLT plasticity (Table 3C), and likelihood-ratio tests showed that the FLT acclimation responses in limpets from Tomales Bay and SF Bay were statistically significantly more positive than in limpets from Elkhorn Slough (Table S2C).

\section{DISCUSSION}

This study compared the plasticity and absolute levels of upper thermal tolerance of foot muscle and cardiac function in the limpet Lottia limatula from sites with different thermal histories. Mortality that occurred during thermal acclimation varied in limpets from across collection locations, as did absolute levels of thermal tolerance. Relationships of thermal tolerance plasticity and thermal habitat varied across collection sites.

\subsection{Upper thermal tolerance differences reflect thermal habitat across collection sites}

Cardiac ABT and FLT values supported the hypothesis that $L$. limatula from warmer sites have higher $\mathrm{CT}_{\max }$ limpets from the warmer sites (Tomales Bay, SF Bay) had higher ABTs and FLTs across acclima- 
tion temperatures compared to limpets from the cooler site (Elkhorn Slough). As limpets from Tomales Bay experience higher maximal habitat temperatures than those from SF Bay, we expected the ABT and FLT Tomales Bay limpets to be higher than that of SF Bay limpets, but that difference was only observed at the highest acclimation temperature $\left(21^{\circ} \mathrm{C}\right)$. The correspondence of species' thermal tolerances with maximal temperatures experienced in their environments has been well documented in many other studies on marine taxa (Stillman \& Somero 1996, Tomanek \& Somero 1999, Tomanek \& Helmuth 2002). Miller et al. (2015) showed that Lottia spp. foot muscle $\mathrm{CT}_{\max }$ was positively correlated with intertidal zone height. For example, L. digitalis lives higher in the intertidal zone than L. limatula (Lindberg 1981), and has an ABT $5^{\circ} \mathrm{C}$ higher than that of L. limatula (Bjelde \& Todgham 2013).

Lower ABT and FLT values of Elkhorn Slough limpets may be attributed to a combination of site and their larger mean body size (Fig. S4). While the site and dry weight variables were confounding, Elkhorn Slough limpets had lower cardiac $\mathrm{CT}_{\max }$ values than Tomales Bay limpets and SF Bay limpets at the same mass (Fig. 5). Furthermore, dry weight did not show significant effects on cardiac $\mathrm{CT}_{\max }$ in the averaged models for all limpets or for the subset of limpets within 1.0-2.0 g. These results suggest that site likely has a greater impact on cardiac $\mathrm{CT}_{\max }$ than body size.

\subsection{No evidence for adaptive plasticity}

There was no evidence that increased acclimation temperature resulted in increased temperature tolerance for foot or heart function, indicating that $L$. limatula are unlikely to benefit from plasticity to reduce the impact of increased habitat temperature. Increasing acclimation temperature from 13 to $17^{\circ} \mathrm{C}$ had a large negative impact on heat tolerance in the least heat tolerant limpets (those collected from Elkhorn Slough), whereas limpets from SF Bay had a similar decline in tolerance between 17 and $21^{\circ} \mathrm{C}$, suggesting that those limpets were at temperatures warmer than their optimal range. These negative ARRs and high cardiac variances of Elkhorn Slough and SF Bay limpets are indicative of physiologically damaging acclimation conditions and insufficient means to sustain responses to stress (Gunderson \& Stillman 2015), which is supported by the mortality of L. limatula observed during exposure to elevated temperatures (Fig. 3). A similar result was found in a study on the cardiac plasticity of the water diving beetle Deronectes spp. (Calosi et al. 2008, Overgaard et al. 2011).

While limpets from Tomales Bay (which had the high cardiac ABT and FLT values) did not suffer a decline in heat tolerance with increasing acclimation temperature, they also did not have the capacity to increase their thermal tolerance. Perhaps Tomales Bay limpets, which experience a relatively variable thermal environment seasonally and annually during their 6-10 yr lifespan (estimated from Dawson et al. 2014), can endure fluctuating temperatures and maintain their high thermal tolerance, either through genetic differentiation or field acclimatization. Future genetic work is needed to confirm that these 3 populations (Tomales Bay, SF Bay, Elkhorn Slough) are reproductively isolated populations, which would expand the inferences regarding local adaptation in these limpets.

\subsection{Differences in heat tolerance of foot and heart muscle differed among sites}

We observed similar levels of heat tolerance between foot and cardiac muscle (i.e. FLT) in limpets from Tomales Bay, whereas foot function was much more heat tolerant than cardiac function in limpets from Elkhorn Slough, as the foot $\mathrm{CT}_{\max }$ did not decline with increasing acclimation temperature in contrast to cardiac FLT. It is possible that the differences between foot and cardiac thermal tolerance lie in physiological differences between these muscles. The limpet foot is a complicated muscular structure which is not as functionally reliant on aerobic metabolism as cardiac muscle. The limpet foot mechanism uses energetically economic smooth muscles to lock into the 'catch' state, which clamps the foot into suction with the substrate (Frescura \& Hodgson 1990, Smith 1991, Galler et al. 2010). Compared to cardiac tissue, limpet foot muscles have low mitochondrial density and high anaerobic capacities (Marshall \& McQuaid 1989, Morley et al. 2009, Suda et al. 2015). If limpets from Elkhorn Slough were in a physiologically compromised state at warmer acclimation temperatures, they may have lacked adequate energy to maintain the aerobic demands of cardiac tissue, whereas the low energetic demands of catch smooth muscle could have been better maintained. It is also possible that the larger mean body sizes of Elkhorn Slough limpets (Fig. S4) could have contributed to increased strain on the cardiac pump, though we do not have any evidence to test that hypothesis. If physiological energetics play a role in maintaining ther- 
mal tolerance of tissues, we would expect energetic state (e.g. adenylate charge) to differ between foot and cardiac muscle differently between limpets from the Tomales Bay and Elkhorn Slough. It would be interesting to know if limpets from those 2 sites differ in other energetic traits (e.g. enzyme levels, maximal performance levels, growth rates, fecundity).

\subsection{Implications for limpets in nature}

We compared thermal tolerances of limpets acclimated to summer maximal average habitat temperatures $\left(17-18^{\circ} \mathrm{C}\right.$ across sites) in order to make environmentally relevant inferences about the thermal ecology of limpets at present during the warmest seasons. We used low-resolution thermal records to infer habitat temperature, but those data are not likely entirely accurate measures of the thermal microhabitats of $L$. limatula across their spatial distribution range. The intertidal zone experiences complex spatiotemporal thermal patterns that are considerably influenced by even fine-scale features such as substratum angle and slope aspect (Helmuth \& Hofmann 2001). The stable temperature, submerged acclimation conditions commonly used in thermal acclimation studies, including ours, do not accurately represent the environmental complexity of the intertidal zone, specifically the interaction of tide and weather that leads to high variability in temperature, salinity, desiccation, and oxygen.

Since acclimation responses of L. limatula thermal tolerance traits were in contrast to expectations, such as what has been described for intertidal crabs and snails (Stillman 2003, Stenseng et al. 2005, Bjelde \& Todgham 2013), it would be worth investigating levels and plasticity of thermal performance traits at a lower range of acclimation temperatures, as well as acclimation to variable temperatures. Under more naturalistic acclimation conditions, physiological shifts may vary (Paganini et al. 2014, Gunderson et al. 2016). L. digitalis acclimated under repeated emersion increase their heat tolerances $4.5^{\circ} \mathrm{C}$ more than submerged limpets (Drake et al. 2017), and L. limatula in their native habitat may be able to increase their heat tolerance beyond what we report. Intertidal zone organisms adapted to fluctuating thermal environments may be under physiological stress during acclimation to sustained high temperatures (Dowd et al. 2015), which could explain the high mortality of Elkhorn Slough limpets in the $21^{\circ} \mathrm{C}$ acclimation even though $21^{\circ} \mathrm{C}$ is not near their thermal tolerance limits. Constant immersion may have resulted in lower thermal tolerances (ABT and FLT) during acute heat exposure in Tomales Bay and SF Bay limpets. In a similar study on L. digitalis, Bjelde \& Todgham (2013) found that emersed limpets on average had $\mathrm{ABTs} 3^{\circ} \mathrm{C}$ higher than immersed limpets. Though not exactly similar to natural conditions, our acclimation conditions at least represent average habitat conditions and allow our results to be comparable to related studies with similar acclimation conditions (Stillman 2003, Stenseng et al. 2005, Bjelde \& Todgham 2013, Armstrong et al. 2019).

\section{CONCLUSIONS}

We have demonstrated that intraspecific variation in thermal physiology exists in individuals from locations with different thermal conditions. Differences in heat tolerance and plasticity could be due to acclimatization (i.e. plasticity), local adaptation, or both. Understanding the mechanisms by which L. limatula from Tomales Bay achieve higher heat tolerance than limpets from other sites may provide novel inferences of the potential for populations of intertidal zone organisms to respond to climate change.

Acknowledgements. We thank Adam Paganini, Emily King, Emily Lam, and Ben Souther for support in the lab. We thank Brittany Bjelde for guidance with measuring limpet heart rates. We also thank Dr. Ted Grosholz for kindly sharing Tomales Bay SST data and Dr. Mark Tanouye for his support at the College of Natural Resources, UC Berkeley. We thank the anonymous reviewers of the manuscript for their helpful comments.

\section{LITERATURE CITED}

Armstrong EJ, Tanner RL, Stillman JH (2019) High heat tolerance is negatively correlated with heat tolerance plasticity in nudibranch mollusks. Physiol Biochem Zool 92: 430-444

* Badgley C, Fox DL (2000) Ecological biogeography of North American mammals: species density and ecological structure in relation to environmental gradients. J Biogeogr 27:1437-1467

Barton K (2019) MuMIN: multi-model inference. R package version 1.43.6

Bjelde BE, Todgham AE (2013) Thermal physiology of the fingered limpet Lottia digitalis under emersion and immersion. J Exp Biol 216:2858-2869

Bjelde BE, Miller NA, Stillman JH, Todgham AE (2015) The role of oxygen in determining upper thermal limits in Lottia digitalis under air exposure and submersion. Physiol Biochem Zool 88:483-493

Bozinovic F, Calosi P, Spicer JI (2011) Physiological correlates of geographic range in animals. Annu Rev Ecol Evol Syst 42:155-179 
Brattstrom BH (1968) Thermal acclimation in anuran amphibians as a function of latitude of altitude. Comp Biochem Physiol 24:93-111

Calosi P, Bilton DTD, Spicer JIJ (2008) Thermal tolerance, acclimatory capacity and vulnerability to global climate change. Biol Lett 4:99-102

Chapperon C, Volkenborn N, Clavier J, Séité S, Seabra R, Lima FP (2016) Exposure to solar radiation drives organismal vulnerability to climate: evidence from an intertidal limpet. J Therm Biol 57:92-100

Chevin LM, Lande R, Mace GM (2010) Adaptation, plasticity, and extinction in a changing environment: towards a predictive theory. PLOS Biol 8:e1000357

Clarke AP, Mill PJ, Grahame J (2000) The nature of heat coma in Littorina littorea (Mollusca: Gastropoda). Mar Biol 137:447-451

* Claussen DL (1977) Thermal acclimation in ambystomatid salamanders. Comp Biochem Physiol 58:333-340

Dahlhoff E, Somero GN (1993) Effects of temperature on mitochondria from abalone (genus Haliotis): adaptive plasticity and its limits. J Exp Biol 185:151-168

* Dawson MN, Hays CG, Grosberg RK (2014) Dispersal potential and population genetic structure in the marine intertidal of the eastern North Pacific. Ecol Monogr 84: 435-456

Denny MW, Miller LP, Harley CDG (2006) Thermal stress on intertidal limpets: long-term hindcasts and lethal limits. J Exp Biol 209:2420-2431

* Diederich CM, Pechenik JA (2013) Thermal tolerance of Crepidula fornicata (Gastropoda) life history stages from intertidal and subtidal subpopulations. Mar Ecol Prog Ser 486:173-187

Dowd WW, King FA, Denny MW (2015) Thermal variation, thermal extremes and the physiological performance of individuals. J Exp Biol 218:1956-1967

Drake MJ, Miller NA, Todgham AE (2017) The role of stochastic thermal environments in modulating the thermal physiology of an intertidal limpet, Lottia digitalis. J Exp Biol 220:3072-3083

Ernande B, Dieckmann U (2004) The evolution of phenotypic plasticity in spatially structured environments: implications of intraspecific competition, plasticity costs and environmental characteristics. J Evol Biol 17:613-628

Fenberg PB, Rivadeneira MM (2011) Range limits and geographic patterns of abundance of the rocky intertidal owl limpet, Lottia gigantea. J Biogeogr 38:2286-2298

Frescura M, Hodgson AN (1990) The fine structure of the shell muscle of patellid prosobranch limpets. J Molluscan Stud 56:435-447

Gabriel W, Lynch M (1992) The selective advantage of reaction norms for environmental tolerance. J Evol Biol 5: 41-59

Galler S, Litzlbauer J, Kross M, Grassberger H (2010) The highly efficient holding function of the mollusc 'catch' muscle is not based on decelerated myosin head crossbridge cycles. Proc R Soc B 277:803-808

Gleason LU, Burton RS (2015) RNA-seq reveals regional differences in transcriptome response to heat stress in the marine snail Chlorostoma funebralis. Mol Ecol 24: 610-627

* Gunderson AR, Stillman JH (2015) Plasticity in thermal tolerance has limited potential to buffer ectotherms from global warming. Proc R Soc B 282:1-8

Gunderson AR, Armstrong EJ, Stillman JH (2016) Multiple stressors in a changing world: the need for an improved perspective on physiological responses to the dynamic marine environment. Annu Rev Mar Sci 8:357-378

*Hamdoun AM, Cheney DP, Cherr GN (2003) Phenotypic plasticity of HSP70 and HSP70 gene expression in the Pacific oyster (Crassostrea gigas): implications for thermal limits and induction of thermal tolerance. Biol Bull (Woods Hole) 205:160-169

*Helmuth BST, Hofmann GE (2001) Microhabitats, thermal heterogeniety, and patterns of physiological stress in the rocky intertidal zone. Biol Bull (Woods Hole) 201:374-384

Helmuth B, Broitman B, Blanchette C, Gilman S and others (2006) Mosaic patterns of thermal stress in the rocky intertidal zone: implications for climate change. Ecol Monogr 76:461-479

IPCC (Intergovernmental Panel on Climate Change) (2014) Summary for policymakers. In: Pachauri RK, Meyer L (eds) Climate change 2014: synthesis report. Contribution of Working Groups I, II and III to the Fifth Assessment Report of the Intergovernmental Panel on Climate Change. Cambridge University Press, Cambridge, p 1-151

Jacobs DK, Haney TA, Louie KD (2004) Genes, diversity, and geologic process on the Pacific coast. Annu Rev Earth Planet Sci 32:601-652

Janzen D (1967) Why mountain passes are higher in the tropics. Am Nat 101:233-249

Khlebovich VV (2017) Acclimation of animal organisms: basic theory and applied aspects. Biol Bull Rev 7:279-286

Kingsolver JG, Huey RB (1998) Evolutionary analyses of morphological and physiological plasticity in thermally variable environments. Am Zool 38:545-560

Kuo ESL, Sanford E (2009) Geographic variation in the upper thermal limits of an intertidal snail: implications for climate envelope models. Mar Ecol Prog Ser 388: $137-146$

* Lee HJE, Boulding EG (2010) Latitudinal clines in body size, but not in thermal tolerance or heat-shock cognate 70 (HSC70), in the highly-dispersing intertidal gastropod Littorina keenae (Gastropoda: Littorinidae). Biol J Linn Soc 100:494-505

Levins R (1968) Evolution in changing environments: some theoretical explorations. Princeton University Press, Princeton, NJ

Lindberg DR (1981) Acmaeidae. The Boxwood Press, Pacific Grove, CA

KLo Presti RM, Oberprieler C (2009) Evolutionary history, biogeography and eco-climatological differentiation of the genus Anthemis L. (Compositae, Anthemideae) in the circum-Mediterranean area. J Biogeogr 36:1313-1332

* Madeira D, Narciso L, Cabral HN, Diniz MS, Vinagre C (2012) Thermal tolerance of the crab Pachygrapsus marmoratus: intraspecific differences at a physiological $\left(\mathrm{CT}_{\max }\right)$ and molecular level (Hsp70). Cell Stress Chaperones 17:707-716

Maechler M, Rousseeuw P, Croux C, Todorov V and others (2019) robustbase: basic robust statistics. R package version 0.93-5

Marais E, Terblanche JS, Chown SL (2009) Life stagerelated differences in hardening and acclimation of thermal tolerance traits in the kelp fly, Paractora dreuxi (Diptera, Helcomyzidae). J Insect Physiol 55:336-343

Marshall DJ, McQuaid CD (1989) The influence of respiratory responses on the tolerance to sand inundation of the limpets Patella granularis L. (Prosobranchia) and Siphonaria capensis Q. et G. (Pulmonata). J Exp Mar Biol Ecol 128:191-201 
Marshall DJ, Rezende EL, Baharuddin N, Choi F, Helmuth B (2015) Thermal tolerance and climate warming sensitivity in tropical snails. Ecol Evol 5:5905-5919

Miller LP, Harley CDG, Denny MW (2009) The role of temperature and desiccation stress in limiting the local-scale distribution of the owl limpet, Lottia gigantea. Funct Ecol 23:756-767

Miller LP, Allen BJ, King FA, Chilin DR, Reynoso VM, Denny MW (2015) Warm microhabitats drive both increased respiration and growth rates of intertidal consumers. Mar Ecol Prog Ser 522:127-143

Morley SA, Hirse T, Pörtner HO, Peck LS (2009) Geographical variation in thermal tolerance within Southern Ocean marine ectotherms. Comp Biochem Physiol A Mol Integr Physiol 153:154-161

Overgaard J, Kristensen TN, Mitchell KA, Hoffmann AA (2011) Thermal tolerance in widespread and tropical Drosophila species: Does phenotypic plasticity increase with latitude? Am Nat 178:S80-S96

Paganini AW, Miller NA, Stillman J (2014) Temperature and acidification variability reduce physiological performance in the intertidal zone porcelain crab Petrolisthes cinctipes. J Exp Biol 217:3974-3980

Pinheiro J, Douglas B, Saikat D (2019) nlme: linear and nonlinear mixed effects models. $\mathrm{R}$ package version 3.1-140

Polgar G, Khang TF, Chua T, Marshall DJ (2015) Gross mismatch between thermal tolerances and environmental temperatures in a tropical freshwater snail: climate warming and evolutionary implications. J Therm Biol 47 : 99-108

Pörtner HO, Bennett AF, Bozinovic F, Clarke A and others (2006) Trade-offs in thermal adaptation: the need for a molecular to ecological integration. Physiol Biochem Zool 79:295-313

R Core Team (2016) R: a language and environment for statistical computing. R Foundation for Statistical Computing, Vienna

Sheldon KS, Tewksbury JJ (2014) The impact of seasonality in temperature on thermal tolerance and elevational range size. Ecology 95:2134-2143

Simon MN, Ribeiro PL, Navas CA (2015) Upper thermal tolerance plasticity in tropical amphibian species from contrasting habitats: implications for warming impact prediction. J Therm Biol 48:36-44

Smith AM (1991) The role of suction in the adhesion of limpets. J Exp Biol 161:151-169

Smith AM (2002) The structure and function of adhesive gels from invertebrates. Integr Comp Biol 42:1164-1171

Smith AM, Quick TJ, St. Peter RL (1999) Differences in the composition of adhesive and non-adhesive mucus from the limpet Lottia limatula. Biol Bull (Woods Hole) 196:34-44

Sokolova IM, Pörtner HO (2003) Metabolic plasticity and

Editorial responsibility: Wen-Xiong Wang,

Kowloon, Hong Kong, SAR critical temperatures for aerobic scope in a eurythermal marine invertebrate (Littorina saxatilis, Gastropoda: Littorinidae) from different latitudes. J Exp Biol 206: 195-207

Somero GN (1997) Temperature relationships: from molecules to biogeography. In: Dantzler WH (ed) Handbook of physiology, Vol 2. Oxford University Press, Oxford, p 1391-1444

Spicer J, Gaston K (2009) Physiological diversity: ecological implication. John Wiley \& Sons, Hoboken, NJ

Stenseng E, Braby CE, Somero GN (2005) Evolutionary and acclimation-induced variation in the thermal limits of heart function in congeneric marine snails (genus Tegula): implications for vertical zonation. Biol Bull (Woods Hole) 208:138-144

Stillman JH (2003) Acclimation capacity underlies susceptibility to climate change. Science 301:65

Stillman J, Somero G (1996) Adaptation to temperature stress and aerial exposure in congeneric species of intertidal porcelain crabs (genus Petrolisthes): correlation of physiology, biochemistry and morphology with vertical distribution. J Exp Biol 199:1845-1855

Suda CNK, Vani GS, de Oliveira MF, Rodrigues E, Rodrigues E, Lavrado HP (2015) The biology and ecology of the Antarctic limpet Nacella concinna. Polar Biol 38: 1949-1969

* Sunday JM, Bates AE, Dulvy NK (2011) Global analysis of thermal tolerance and latitude in ectotherms. Proc R Soc B 278:1823-1830

* Symonds MRE, Moussalli A (2011) A brief guide to model selection, multimodel inference and model averaging in behavioural ecology using Akaike's information criterion. Behav Ecol Sociobiol 65:13-21

Test ARG (1945) Ecology of California Acmaea. Ecology 26: 395-405

พ Tomanek L, Helmuth B (2002) Physiological ecology of rocky intertidal organisms: a synergy of concepts. Integr Comp Biol 42:771-775

*Tomanek L, Somero GN (1999) Evolutionary and acclimation-induced variation in the heat-shock responses of congeneric marine snails (genus Tegula) from different thermal habitats: implications for limits of thermotolerance and biogeography. J Exp Biol 202:2925-2936

Willett CS (2010) Potential fitness trade-offs for thermal tolerance in the intertidal copepod Tigriopus californicus. Evolution 64:2521-2534

Zippay ML, Hofmann GE (2010) Physiological tolerances across latitudes: thermal sensitivity of larval marine snails (Nucella spp.). Mar Biol 157:707-714

Zuur AF, Ieno EN, Walker NJ, Saveliev AA, Smith GA (2009) Mixed effects models and extension in ecology with R. Springer, New York, NY

Submitted: February 19, 2019; Accepted: August 1, 2019 Proofs received from author(s): September 17, 2019 